Int. J. Electrochem. Sci., 15 (2020) $4556-4566$

International Journal of

ELECTROCHEMICAL

SCIENCE

WWW.electrochemsci.org

\title{
Preparation of DNA-Based Biosensor for Electrochemically Identification of Transgenic Soybean
}

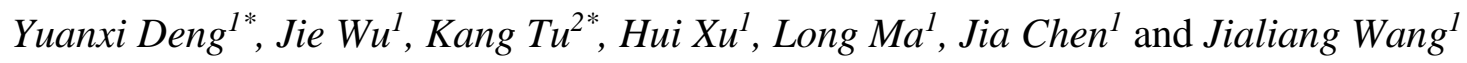 \\ ${ }^{1}$ College of Food and Bioengineering, Bengbu University, Anhui, 233030. P.R. China \\ ${ }^{2}$ College of Food Science and Technology, Nanjing Agricultural University, Jiangsu, 210095, P.R. \\ China \\ *E-mail: Yuanxi Deng: 278967574@qq.com Kang Tu: Kangtu163@foxmail.com
}

doi: $10.20964 / 2020.05 .09$

Received: 24 December 2019 / Accepted: 3 February 2020 / Published: 10 April 2020

\begin{abstract}
Since the successful transformation of the first transgenic soybean, the variety and planting area of transgenic soybean have increased. Therefore, transgenic soybean identification has become a necessary procedure in gm research. The development of rapid, sensitive, high-throughput and newly automated detection methods has become a hot spot in the detection of transgenic products. In this paper, we modified a layer of a partially reduced graphene oxide film on the surface of an ionic liquid carbon paste electrode by a green, controlled electrochemical reduction method. We fixed the probe on the electrode surface by covalently bonding the remaining oxygen-containing groups on the electrode surface with an end-modified amino group. Then, the hybridization reaction was detected with methylene blue as an indicator after hybridization between the electrode and the target sequence, and the transgenic soybean sequence was detected by differential pulse voltammetry. We also tested PCR products of DNA extracted from actual samples.
\end{abstract}

Keywords: Graphene oxide; Electroreduction; DNA sensor; Transgenic soybean; Surface modification

\section{FULL TEXT}

(C) 2020 The Authors. Published by ESG (www.electrochemsci.org). This article is an open access article distributed under the terms and conditions of the Creative Commons Attribution license (http://creativecommons.org/licenses/by/4.0/). 